\title{
Factors affecting strategic relations: a study of China's internationalization policy with a view to relationships with Pakistan
}

\section{Talib Hussain}

Department of Business Management, University of Baltistan, Skardu, Gilgit-Baltistan, Pakistan

Sajjad Ali

School of Sociology and Political Science, Shanghai University, 99 Shangda Road, Baoshan District, Shanghai China

\section{Shahid Hussain}

Department of Business Management, University of Baltistan, Skardu, Gilgit-Baltistan, Pakistan

Xiaocong Lu

School of Sociology and Political Science, Shanghai University, 99 Shangda Road, Baoshan District, Shanghai China

\begin{abstract}
China's President Xi Jinping's formal visit to Pakistan on 20-21April 2015 marks as a milestone in the development of China-Pakistan relations. Keeping in view the president's Xi's visit in 2015, the first part of the study assesses the significant outcomes of Xi's visit and its implications with reflections to literature. It considers the most essential, economic, political and social consequences for both countries' bilateral relations. The second part of the study focuses on measuring the most influencing factors for country relations through ranking the most highlighted factors of two neighbouring countries during Xi's visit in 2015. In literature, researchers try to evaluate the visits of the country head and its impact on the countries' relations through qualitative methods. In this unique study, the researchers have surveyed to define the levels of elements which are supposed to be more important during Xi's visit for both country relations in a quantitative way. Thus, this paper is potentially original for applying a predominantly mathematical analysis for measuring country head visits and bilateral relations of countries; which has been so far evaluated predominantly by qualitative analysis. In this current study, the ranking and weights of the matrices show that during Xi's visit to Pakistan in 2015, the significant contributions towards China Pakistan relations were more economical. Therefore, this paper contributes to the literature in the sense that it provides a mathematical equation to measure the factors contributing to bilateral relations for any country head/delegation visit to any other country. Future studies may include some other elements besides political, economic, and social to measure the country relations quantitatively.
\end{abstract}

\section{Keywords}

Analytic Hierarchy Process; strategic alliance; regional economic growth; country relations

\section{Introduction}

China's President, Xi Jinping's formal visit to Pakistan on 20-21 April 2015 marks yet another milestone in the development of China-Pakistan relations (Ahmar, 2015). This visit has taken China and Pakistan closer together than ever before, thus laying the basis for a stronger and more efficient partnership (Heilmann, Rudolf, Huotari, \& Buckow, 2014). Notably, the higher level of mutual trust has made them more contented in pursuing closer economic, security, and social cooperation, and holds substantial implications for the whole region (Rizvi, 2015). President Xi Jinping is the 
second Chinese leader to visit Pakistan in the 2010s after Chinese Premier Li Keqiang's visit to Pakistan in May 2013 (Khan, 2014). This visit is also Xi's first overseas trip of 2015 which has led to the mutual agreement of accords for $\$ 46$ billion of investment in Pakistan by China for the construction of roads, rails and power plants to be built on a commercial basis by Chinese companies over 15 successive (Haq \& Farooq, 2016). Added to that, this visit indicates the endorsing of the deal of eight Chinese submarines, more than double Pakistan's marine (Hali, Shukui, \& Iqbal, 2015).

International media reports remarkably cover it. In the United States, the New York Times, claims that it is a signal likely to confirm the decline of American influence in Pakistan. CNN states that this trip is as a milestone for the development of the developing country. Al Jazeera presents such visit as a way for Beijing to access the Arabian Sea to increase its trade with Europe, the Middle East, and Africa. The Washington Post describes this trip as more economical than political. The BBC news reports that the Chinese state and its banks would lend to Chinese firms to carry out the work, thus making it a viable project with a direct impact on China's economy. Literature suggested that sharing economy is one of the best factors to boost economies (Nica, 2018). The Times of India and Hindustan Times remark that during Xi's visit, Pakistan conferred its highest civilian award Nishan-e-Pakistan to Xi Jinping for his outstanding contribution in promotion of China's relationship with Pakistan (Chen, Joseph, \& Tariq, 2018).

The President Xi Jinping was supposed to visit Pakistan in 2014 during his South Asia trip to India, Maldives, and Sri Lanka but he suspended it due to political unrest in the country. In some media channels reports, Xi Jinping's trip to Pakistan was to attend the Pakistan Day parade in February 2015, in the milieu of President Obama's visit to India. After these delays and long time, the Chinese foreign minister Wang Yi confirmed that Xi Jinping would be making his first state visit to Pakistan in April 2015. Eventually, on 20-21April 2015, President Xi visited Pakistan, and fifty-one MoUs have been signed for the betterment of two countries (Fallon, 2015).

Keeping in view the long-lasting bilateral relationships and president's Xi's visit in 2015; the first part of the study assesses the Xi's visit's significant outcomes and their implications with reflections to literature review for both countries relations. The first part of the study reviews recent developments in the maturing partnership between
China and Pakistan; it considers the most critical recycled economic, political and social outcomes; it also offers an in-depth analysis of the Chinese lifting major activities in Pakistan. The second part of the study focuses on the most outcomes/highlighted factors of the bilateral relations between these two neighbouring countries during Xi's visit (Abid \& Ashfaq, 2015).

In literature, it is found that there is no logical evaluation and a mathematical model to measure whether the official visit of country head/delegation measured effectually or not. It can be seen that the researchers try to evaluate the trips or visits of the country heads/delegations and its impact on the countries' relations through qualitative methods. Due to the chances of biases of researchers' in qualitative research, the reliability of these findings limits the studies, and there is no more use of the results for further policy implementations.

In this unique study; first, the researchers' have conducted an in-depth literature review and interviewed to fix the main issues highlighted during and the aftermath of the president's Xi's visit in 2015 to Pakistan. After defining the major issues and factors highlighted in this trip, a survey was conducted with respondents to define the levels of elements which are supposed to be more important during this visit for both countries relations. President Xi's visit to Pakistan in 2015 has been taken as the core study target and grounded it to modelling an Analytic Hierarchy Process method to measure the main factors affecting China-Pakistan relations.

To construct a mathematical model for measuring country head visit's pros and cons; researchers have ranked the highlighted factors through the mathematical and conceptual model with evaluation impact indexes. In this paper, it is claimed that it uses a quantitative way to measure the country heads' visit and its outcomes very first time; previously, it has measured through qualitative ways. The current research makes use of the Analytic Hierarchy Process (AHP) model to measure the main outcomes of Xi's visit to Pakistan in 2015 to measure factors affecting China-Pakistan relations.

AHP is best used by researchers (Saaty, 2008) as a technique of organization and analysis based on mathematics, but its application received credit in many sectors requiring complex decisionmaking, especially in business and other social sciences. More recently, AHP is also used in processes of complex decision-making that need the evaluation of several components, including 
also qualitative assessments and having a longerterm impact and high stakes.

This paper is potentially original for applying a predominantly mathematical analysis for measuring country head visits and bilateral relations; which has been so far evaluated mainly by qualitative studies.

\section{History of China- Pakistan relations: a literature review}

Pakistan and China have a long history of consistent, friendly relationships. These two countries have proven a model for other countries to have regular and reasonable relations. Although the changes took place in governments of both states, the relationshipsdid not affect over time. These two countries always respect each other's freedom, sovereignty, territorial integrity, and political diplomacy. These relations boost the economic and social development in each country because of sharing economy (Popescu, 2018). Pakistan has always supported China in its Tibet and Taiwan issues while China also has assisted Pakistan in its Kashmir issues and offered its economic and trade assistance(Kazimi, 2016). As compared to all of China's neighbouring countries, the China-Pakistan relations are the closest and friendliest for many years (Afridi \& Bajoria, 2010). The two countries always enjoyed close collaboration in areas such as trade, border sharing, and their military assistance. China is not only striving to be a good friend of Pakistan, but it also threatens the United States and some other world powers by economic development (Bijian, 2005). The China-Pakistan friendship of several years now has a new objective - to improve the economic, security, and social content of their relationship, which comprises trade, investment, and energy cooperation within a bilateral framework. The relations seem to be more economical in the history, and the trade provides China access to a new market for its goods and for a foreign investment opportunity for Pakistan (Kataria \& Naveed, 2014). In this study, the history of bilateral relations has been limited to the era of 2000-2015.

\subsection{Visits of China- Pakistan country heads/delegations in the past and some highlighted issues 2000-2015}

In January 2000 Pakistan's Chief executive visited China for bilateral relations. He met the Chinese Primer Zhou Rongji and discussed recent tensions between US sanctions on Pakistan's nuclear policy and democracy-related issues. The visit was concluded with remarkable comments by Chinese Premier Zhou Rongji that the Pakistan- China relations will not be affected irrespective of the military government in Pakistan (Kataria \& Naveed, 2014). In 2001, Chinese primer visited Pakistan, and Gawadar port project was the main subject in this visit. The authorities also discussed the relations on security (Tao, 2012).

In December 2001, Pakistani president Pervez Musharraf visited China. He met Chinese president Jiang Zemin. The leadership discussed the bilateral relationship under the umbrella of the terrorists attack in the World Trade Centre on 11 September 2001. The visit was concluded with the remarks that Pakistan's assistance to the US for the war on terror would not affect China-Pakistan relations (Sattar, 2007).

In 2002, China became an active player with the US and European Union determinations to stop tensions, i.e. war between Pakistan and India. On March 2003 the PM of Pakistan Jamali visited China and met with Chinese new Prime Minister Wen Jiabao. The peaceful nuclear plant, transmission, and to establish a Pakistan-China friendship forum were the primary outcomes of this visit (AbdulHaq, 2015).

On April 2005, Chinese Premier Wen Jiabao's visited Pakistan. This trip was remarkable in establishing a new era of bilateral relations. Both sides' authorities signed twenty-one agreements to promote close trade and economic ties, and the free trade plans were one of these agreements which were highlighted in the media (Sattar, 2007).

On November 2006, the Chinese President Hu Jintao visited Pakistan. During this trip, President Hu Jintao met with high Pakistani officials, and both countries signed MoUs for stronger bilateral relations. The Chinese President Hu Jintao was awarded the highest civil award of Nishan-IPakistan on his excellences and ideal leadership.

On August 2008, the Prime Minister of Pakistan Yousaf Raza Gilani visited China to attend the Beijing Olympics. The PM of Pakistan met with Chinese President Hu Jintao, and the same year PM of Pakistan visited China second time and attained the Asia Europe Summit Meeting and signed many projects.

In 2009, the President of Pakistan Asif Ali Zardari visited Chinese provinces Hangzhou and Guangzhou. In this trip, the leadership of both countries signed Memorandum of Understanding for cooperation in the field of fisheries. In this same year, the Prime Minister of Pakistan Yousaf Raza 
Gilani went to China to attain the meeting of the Shanghai Cooperation Organization, and he also met the top leadership of China and signed different contracts.

In 2010 the president of Pakistan visited China on the special invitation of Chinese President to attend the opening ceremony of the 16th Asian Games. The Prime Minister of China, Wen Jiabao also visited Pakistan in 2010. During this visit, The PM of China met the high officials of Pakistan and inaugurated the "Pakistan-China Friendship Centre" in Islamabad.

In 2011, the President of Pakistan Asif Ali Zardari visited China to attend the China-Eurasia Expo and met with the high official of China, including the president of China. In the same year, Prime Minister of Pakistan Mr Gilani visited China to attain the Shanghai Cooperation Organization (SCO). During these two visits, the leadership of both countries insisted on having strong relations between China and Pakistan.

In 2012, Chief of Army Staff of Pakistan General Ashfaq Kiyani, PM of Pakistan Yousaf Raza Gilani, President of Pakistan Asif Ali Zardari and Pakistani parliamentary delegation visited China in different dates. All these visits resulted in signing in different bilateral agreements on trade, peace, and security.

In 2013, Pakistani PM Visited China on the invitation of Chinese Premier, and during this visit, several projects were discussed(Pantucci, 2014).

In 2014, President of Pakistan Mamnoon Hussain visited China as his first official trip and met with his counterpart of China and signed many MoU, and in the same year of 2014, the PM of Pakistan visited China and signed 19 agreements including CPEC.

On April 2015, Chinese President Xi Jinping visited Pakistan. During this trip, the Chinese president met with many high officials of Pakistan and signed 51 MoUs, including the plan of "Pakistan China Economic Corridor." In the same year, PM of Pakistan attends the prime ministers' meeting of the Shanghai Cooperation Organization (SCO) secession as the representative of an observer state.

Based in the literature related to China- Pakistan relations and the outcomes which have been highlighted in the forgoing visits of different delegations of both countries and through in-depth interviews there were selected factors which affect China- Pakistan relations. All these factors have been analyzed through AHP mathematical model. The coming section describes the ranking and other matrix analysis techniques for this quantitative study.

\section{Model of Analysis}

Measuring country relations by the country head/delegation visits is not an easy task. During and after country heads visits; research, media personals and politicians are always trying to evaluate these visits. Keeping in mind the previous literature and the outcomes of the Xi's visit to Pakistan in the media and other reports and on the bases of in-depth interviews; the model for evaluating country relations was developed. This model was pre-tested and found valid to measure the factors affecting country relations in the visits of the country heads through AHP.

\subsection{Methods of Constructing Factors}

China-Pakistan relations were first defined in the dependent and independent variables. Country relations were defined as the dependent variable, and the political, social, and economic actions are taken as independent variables and treated as midlevel factors in the indexes for AHP modeling. To measure each independent variable, there were defined sub-constructs, which are treated as lower factors in AHP model. Further details were provided in the forthcoming sections. This section discusses the key variables used in this study, along with the nature of the variables.

\subsubsection{Dependent Variable Level}

- Country relations

2.2.2. Independent Variables (mid-level)

- Political Actions

- Social Actions

- Economic Actions

\subsubsection{Lower Factors Level}

- Defence Co-operation

- Country image

- War on terror

- Regional Stability

- Cultural Relations

- Cooperation in the disaster

- Education Exchanges

- Health services

- Trade Co-operation

- Energy Co-operation

- Foreign Direct Investment

- Infrastructure 


\subsection{Explanation of key elements}

\subsubsection{Country relations}

Althoughmany factors that affect country relations can be found in literature, here, in this study, it is only dependent on three main factors, political, social, and economical. These factors are extracted from different interviews and literature review. During Xi's visit to Pakistan, these factors were highlighted, and many projects related to these factors are assigned to boost both country relations.

- Political actions

Political relations of countries are always on the top priority to get more benefits. After careful literature review and in-depth qualitative interviews, the authors selected:defence cooperation, country image, military relations, and regional security, as factors responsible for political relations of countries in China Pakistan settings. These factors are also highlighted during Xi's visit to Pakistan in 2015.

\section{Defence co-operation}

In the history of China and Pakistan, there can be seen a lot of defence agreements where both countries have promised each other to boots up the ties in defence. This co-operation is especially important for Pakistan, as China serves the purpose of a high- value guarantor against India. The premier president of Pakistan Musharraf's February 2006's visit to China and the subsequent visit by the Pakistan Air Force (PAF) Chief to China has proven the defence relations between the two states. On 23 May 2006, Pakistan clinched a \$600 million defence deal with China, which is also one of the major defence agreements between two neighbour countries. Recent developments in defence cooperation between these neighbour countries can be seen in the light of many defence projects in CPEC. The US former president, Bush's visit to India and a formation of a nuclear deal between US and India, bring Pakistan closer to China. Pakistan fails to have nuclear co-operation with the US just like India have. To overcome the threat from India, Pakistani authorities started to have dialogues with China. Pakistan succeeds to get more nuclearcooperation with China like; the short and medium range solid fuel missile technology, and the likely partner in the development of Pakistan's Land Attack Cruise Missile which was tested by Pakistan in 2005. In 2006 visit of Pakistani President Musharraf's, an agreement was signed to build cooperation in the peaceful application of nuclear energy. Literature also suggested that technological advancement is leading countries toward sustainable economic development

\section{Country image}

In the trips of the country heads, every country tries to build its image through media reports and by other sources. Sometimes many international media channels independently give coverage of such official trips. During the Xi's visit to Pakistan in 2015, on one side, the international media was very active, and on another side, both countries image was gone up.

\section{War on Terror}

The Joint Marine Research Centre established under the CPECproject is one of the major political outcomes of the Xi's visit to Pakistan, which shows the interest of both countries for the war on terror.

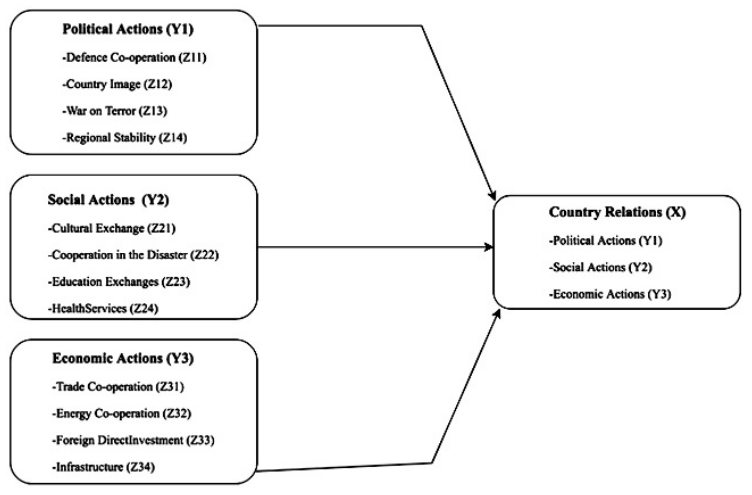

Figure $1 \mathrm{~A}$ conceptual model to measure factors for country relations

Source: The authors

\section{Regional Stability}

One of the major outcomes of president Xi's visit to Pakistan in 2015 was also to ensure regional security. On the one side they signed many security-based agreements, and on the side, president $\mathrm{Xi}$ was also pleased to boost both countries relations with the mutualagreements for stable regional security.

\section{- Social actions}

To keep the broader country relations, every nation tries to have some social activities in other nations. In case of China-Pakistan relations, and in the light of the Xi's visit to Pakistan in 2015 cultural relations, cooperation in the disaster, education exchanges, and health services were taken as the main factors for social relations of both countries. 


\section{Cultural relations}

In September 1999, the Pakistani government cultural delegation visited China. These cultural exchanges were very useful in the field of art, education, health, sports, literature, and information. In literature, quite a few writings from two sides were translated into each other's language. In the $1980 \mathrm{~s}$, a special agreement has been signed between two states to promote cultural interaction in the field of TV and film. Both states give importance to cultural relations to increase people to people cooperation for strong PakistanChina relations. China appreciates Pakistani's effort to expand Chinese language and Confucius Institutes in Pakistan. The recent President Xi's Visit also recalled the previous agreements and cooperation and promised to have more strong cultural relations.

\section{Cooperation in the disaster}

Pakistan and China have faced an earthquakedisaster in 2005 and 2008, respectively. Cooperation of both states showed their time test and strong relations at the time of need. In October 2005, a dreadful earthquake hit Pakistan and some areas of neighbouring countries. After the earthquake disaster, in the first week, China provided $\$ 6.2$ million in aid to Pakistan. This aid included new 150000 blankets and 3380 tents worth of 50 million Yuan. Total aid package from China reaches up to $\$ 20.5$ million. Pakistan's cabinet Sectary Ejaz Rahim stated, "We cannot forget that China is amongst the first countries to leap to the assistance of the people of Pakistan and it has done it whenever Pakistan is in need."

In 2010, Pakistan faced the worst flood disaster of history, causing huge losses in life. This disaster affected eighteen million population of Pakistan. It also destroys infrastructure, roads, homes, bridges, irrigation system, crops and livestock's and spread diseases environmental and social issues. China is one of the first countries which offered immediate aid after the flood disaster. China has sent its medical team to assist the people of affected areas. The Chinese government, social organizations, and common people also denoted aid for Pakistani people.

\section{Education exchange}

China-Pak educational exchanges and cooperation have always developed in history. In 2003, cooperative education exchanges programs were started between Pakistan and China. During Xi's visit to Pakistan in 2015, he announces to double the scholarships for Pakistani students. In recent time thousands of Pakistani students are getting higher education in China. There are also many exchange students under cultural and educational programs.

\section{Heath services}

To boost the services of health in the light of China Pakistan relations; Gwadar hospital is one example of the social works of China under CPEC, and it is announced during the Xi's visit to Pakistan in 2015. After the announcement of these social works China Pakistan, bilateral relations became stronger.

\section{- Economic actions}

Behind the political and social relations, each country in the world tries to have an economic interest in every field of relations. As technology has a positive impact on economic development (Hardingham, Vrbka, Kliestik, \& Kliestikova, 2018). China-Pakistan also has many projects which are based on the mutual relations and for economicinterest. The economicinterest of both countries can be seen in the developments of China Pakistan relation throughout history. To evaluate the China-Pakistan economic relations, trade cooperation, energy co-operation, foreign direct investment, and infrastructure are taken as responsible factors on the bases of literature review and in-depth interviews.

\section{Trade co-operation}

Despite the world economic problems, Pakistan-China trade increases by $18.2 \mathrm{pc}$ to $\$ 4.4$ billion in 2016. During Musharraf's February 2006 visit, Pakistan becomes an observer of the Shanghai Co-operation Council. This is a great achievement of Pakistan and also a milestone for future relations. A free trade agreement (FTA) was signed between Pakistan and China in 2006 and implemented in 2007. The technological advancement which China specially transfers to Pakistan will help to fulfil the labour requirement and trade relations in industry (Mitea, 2018; Neary, Horák, Kovacova, \& Valaskova, 2018).

\section{Energy co-operation}

In 2014, Chinese Prime Minister announced an investment of $\$ 31.5$ billion in Pakistan, mainly in country's energy, infrastructure, and Gwadar port expansion. According to the newspaper, The Express Tribune, initial projects worth \$15-20 billion will be started which include LahoreKarachi motorway, Gwadar Port expansion, and 
energy sector projects will be launched in Gadani and six coal projects near Thar coalfield. The newspaper further claimed that the government also handed over to Pakistan Army the task of providing fool-proof security to Chinese officials in Baluchistan, Pakistan in a bid to address Beijing's concerns and execute the investment plan in the province, which will get $38 \%$ of the funds (Fallon, 2015).

\section{Foreign direct investment}

In 2006, President Musharraf visited China, which became a landmark in Pakistan-China friendship history for private investment. China announces to increase investment in Pakistan from $\$ 500$ million to $\$ 12$ billion, which would be used to make joint venture companies and private investments.

\section{Infrastructure}

China Pakistan always seems serious to build the infrastructure for better relations and economic activity. The Karakoram Highway, CPEC, and China's news dream of one road one billet are few of the major projects which enable both countries to increase the trust for future business and cooperation through better infrastructure.

\section{Data analysis and results}

For ranking and comparing the matrices, the Analytic Hierarchy Process method was used. The researchers invited 41 respondents to rank the factors. Nine-point scale method was used for ranking. Table 1 shows the associating of $i$ and $j$, and it clarifies the nine-point scale method. The forthcoming sections describe the criteria of formulating matrices and the analysis techniques, including the reliability of the study.

Table 1 Resultant matrix scale and ranking techniques Judgment scale matrix

\begin{tabular}{c|l|c}
\hline No & Rank & Aij \\
\hline 1 & i and j are equally important & 1 \\
\hline 2 & i is a little more important than $\mathrm{j}$ & 3 \\
\hline 3 & i is important than $\mathrm{j}$ & 5 \\
\hline 4 & i is more highly important than $\mathrm{j}$ & 7 \\
\hline 5 & i is extremely important than $\mathrm{j}$ & 9 \\
\hline 6 & i is a little less important than $\mathrm{j}$ & $1 / 3$ \\
\hline 7 & i is obviously less important than $\mathrm{j}$ & $1 / 5$ \\
\hline 8 & i is highly less important than $\mathrm{j}$ & $1 / 7$ \\
\hline 9 & i is extremely less important than j & $1 / 9$ \\
\hline
\end{tabular}

\subsection{General criteria for formulating the comparing matrix}

The respondents have been asked to rank different elements for comparisons with respectiveto dependent variable "country relations," and independent variables political relations, social relations and for economic relations. For dependent variable "Country Relations," there are three compressions; thus, the researchers developed three by three matrixes for country relations. There are six comparisons for political, social, and economic relations. Therefore the researchers have four by four matrices for all these independent variables. Here, the diagonal elements of the matrixes are always 1 , and there is a need to fill up the upper triangular matrix only. The following rules are used to fill up the upper triangular matrix i:

The formula to fill:

1. First, we filled the upper side of the matrices.

2. In the second stage, we took the reciprocals of upper side to fill the lower side of matrices.

Reciprocal values of the upper diagonal were used to fill the lower triangular matrix. The following formula was used to fill the matrices:

$$
a_{\bar{\jmath}}=\frac{1}{a_{\bar{\iota}}}
$$

\subsection{Ranking the elements for building decision matrices}

To draw the decision matrices, the researchers build the average matrices of dependent and independent variables.

\subsubsection{Country relations}

By the responses collected from 41 respondents, the following matrix was built for country relations

Table 2 Matrix for country relations

\begin{tabular}{c|l|c|c|c}
\hline \multicolumn{2}{c}{ Country Relations } & a & b & c \\
\hline a & $\begin{array}{l}\text { Political } \\
\text { Relations }\end{array}$ & 1 & $55 / 6$ & $53 / 5$ \\
\hline b & Social Relations & $6 / 55$ & 1 & $52 / 7$ \\
\hline c & $\begin{array}{l}\text { Economic } \\
\text { Relations }\end{array}$ & $6 / 53$ & $7 / 52$ & 1 \\
\hline
\end{tabular}


- Resultant matrix of Y1, Y2, Y3 concerning $\mathrm{X}$ (country relations)

$$
d 1=\left[\begin{array}{ccc}
1 & \frac{55}{6} & \frac{63}{5} \\
\frac{6}{55} & 1 & \frac{52}{7} \\
\frac{6}{53} & \frac{7}{52} & 1
\end{array}\right]
$$

\subsubsection{Political actions}

By the responses collected from 41 respondents for political relations to build overall country relations, the following matrix was built

Table 3 Matrix for political actions

\begin{tabular}{c|l|c|c|c|c}
\hline \multicolumn{2}{c|}{ Political Actions } & a & b & c & d \\
\hline a & $\begin{array}{l}\text { Defenceco- } \\
\text { operation }\end{array}$ & 1 & $51 / 5$ & 6 & $55 / 8$ \\
\hline b & $\begin{array}{l}\text { Country } \\
\text { image }\end{array}$ & $\begin{array}{c}5 / 5 \\
1\end{array}$ & 1 & $51 / 2$ & $55 / 6$ \\
\hline $\mathrm{c}$ & War on terror & $1 / 6$ & $2 / 51$ & 1 & $53 / 4$ \\
\hline $\mathrm{d}$ & $\begin{array}{l}\text { Regional } \\
\text { stability }\end{array}$ & $\begin{array}{c}8 / 5 \\
1\end{array}$ & $6 / 55$ & $4 / 53$ & 1 \\
\hline
\end{tabular}

- Resultant matrix of Z11, Z12, Z13, Z14 with respect to Y1 (Political Relations)

$$
d 2=\left[\begin{array}{cccc}
1 & \frac{51}{5} & 6 & \frac{55}{8} \\
\frac{5}{51} & 1 & \frac{51}{2} & \frac{55}{6} \\
\frac{1}{6} & \frac{2}{51} & 1 & \frac{53}{4} \\
\frac{8}{51} & \frac{6}{55} & \frac{4}{53} & 1
\end{array}\right]
$$

\subsubsection{Social Relations}

By the responses collected from 41 respondents for social actions to build country relations via social actions/relations the following matrix was built.

Table 4 Matrix for country relations

\begin{tabular}{c|l|c|c|c|c}
\hline \multicolumn{2}{|l|}{ Social Actions } & a & b & c & d \\
\hline a & Cultural Exchange & 1 & $53 / 5$ & $52 / 5$ & $\begin{array}{c}5 \\
7 / 9\end{array}$ \\
\hline b & $\begin{array}{l}\text { Cooperation in the } \\
\text { disaster }\end{array}$ & $5 / 53$ & 1 & $52 / 5$ & $\begin{array}{c}4 \\
2 / 5\end{array}$ \\
\hline c & Education Exchanges & $5 / 52$ & $5 / 52$ & 1 & $\begin{array}{c}5 \\
1 / 5\end{array}$ \\
\hline$d$ & Health Services & $3 / 19$ & $5 / 42$ & $5 / 51$ & 1 \\
\hline
\end{tabular}

$$
\mathrm{d} 3=\left[\begin{array}{cccc}
1 & \frac{53}{5} & \frac{52}{5} & \frac{57}{9} \\
\frac{5}{53} & 1 & \frac{52}{5} & \frac{42}{5} \\
\frac{5}{42} & \frac{5}{52} & 1 & \frac{51}{5} \\
\frac{3}{19} & \frac{5}{42} & \frac{5}{51} & 1
\end{array}\right]
$$

\subsubsection{Economic relations}

By the responses collected from 41 respondents for economic actions to build country relations following matrix was built for country relations.

Table 5 Matrix for country relations

\begin{tabular}{c|l|c|c|c|c}
\hline \multicolumn{2}{c|}{ Economic actions } & a & b & c & d \\
\hline a & Trade co-operation & 1 & $53 / 5$ & $51 / 2$ & $\begin{array}{c}6 \\
1 / 8\end{array}$ \\
\hline b & Energy co-operation & $5 / 53$ & 1 & 6 & $\begin{array}{c}5 \\
1 / 7\end{array}$ \\
\hline c & FDI & $2 / 51$ & $1 / 6$ & 1 & $\begin{array}{c}5 \\
2 / 3\end{array}$ \\
\hline d & Infrastructure & $8 / 61$ & $7 / 51$ & $3 / 52$ & 1 \\
\hline \multicolumn{2}{|c|}{} & \multicolumn{4}{c}{ Source:The authors }
\end{tabular}

- Resultant matrix Z31, Z32, Z33, Z34 concerning Y3 (Economic actions)

$$
\mathrm{d} 4=\left[\begin{array}{cccc}
1 & \frac{53}{5} & \frac{51}{2} & \frac{61}{8} \\
\frac{5}{53} & 1 & 6 & \frac{51}{7} \\
\frac{2}{51} & \frac{1}{6} & 1 & \frac{52}{3} \\
\frac{8}{61} & \frac{7}{51} & \frac{3}{52} & 1
\end{array}\right]
$$

\subsection{Reliability}

To calculate the ordering vector of every element eigenvectors $\mathrm{F}$ corresponding to its maximum distinctive root $\lambda \max$.

1. The equation to measuring the resultant matrix geometric mean of all the elements of each row $\mathrm{W}^{\prime}=$

$$
\mathrm{w}^{\prime}=\left(\mathrm{w}_{1}^{\prime}, \mathrm{w}_{2}^{\prime}, \mathrm{w}_{3}^{\prime}, \ldots, \mathrm{w}_{\mathrm{n}}\right)^{T}=\left(\sqrt[n]{\prod_{j=1}^{n} \mathrm{a}_{1 j}}, \sqrt[n]{\prod_{j=1}^{n} \mathrm{a}_{2 j}}, \ldots ., \sqrt[n]{\prod_{j=1}^{n} \mathrm{a}_{n j}}\right)^{T}
$$

Resultant matrix of Z21, Z22, Z23, Z24 concerning Y2 (Social actions) 
2. For standardization of each element of the vector $\mathrm{W}^{\prime} \mathrm{W}=$

$\left(w 1, w 2, w 3, \ldots, w n 3, \ldots \mathrm{w}^{\prime} \mathrm{n}\right)^{T}=$

$$
\left(\frac{w_{1}^{\prime}}{\sum_{i=1}^{n} w_{i}^{\prime}}, \frac{w_{2}^{\prime}}{\sum_{i=1}^{n} w_{i}^{\prime}} \ldots \ldots \ldots \ldots \ldots, \frac{w_{n}^{\prime}}{\sum_{i=1}^{n} w_{i}^{\prime}}\right)^{T}
$$

3. Calculation of maximum eigen value $\lambda \max$ the resultant matrix $=\lambda \max =$

$$
\sum_{i=1}^{n} \frac{(A W)_{i}}{n w_{i}},\left(A W_{i}^{\prime}\right)
$$

It is the element of vector AW

4. Consistency check index towards resultant matrix validity check

$$
\mathrm{CI}=\frac{\lambda \max -\mathrm{n}}{\mathrm{n}-1}
$$

5. For more information and random consistency ratio index

$$
\mathrm{CR}=\frac{\mathrm{CI}}{\mathrm{RI}}(\mathrm{n} \geq 2)
$$

The consistency can be checked through these equations and by using the calculations of Tables 2 , 3,4 and 5. The matrix will be consistent and valid if $\mathrm{CR}<0.10$. The following Random Consistency Index 1 in Table 6, also depicts the differences conferring to the various orders of the matrix. In this study, the comparison matrix was put into Matlab to see how different is the result of numerical computation of Eigen value and Eigen vector compared to this study results. Following with AHP method, the researchers measured the consistency ratio values for every judgment matrix, which were: 0.0986, 0.0787, 0.0984, and 0.891. All these values are below 0.1 . This confirms that all judgment matrices fulfil the consistency check, and results are reliable for further decision making.

Table 6 Random consistency index (RI) 1

\begin{tabular}{l|l|l|l|l|l|l|l|l|l|l}
\hline $\mathbf{N}$ & $\mathbf{1}$ & $\mathbf{2}$ & $\mathbf{3}$ & $\mathbf{4}$ & $\mathbf{5}$ & $\mathbf{6}$ & $\mathbf{7}$ & $\mathbf{8}$ & $\mathbf{9}$ & $\mathbf{1 0}$ \\
\hline $\mathrm{RI}$ & 0 & 0 & 0.6 & 1 & 1.1 & 1.2 & 1.3 & 1.4 & 1.5 & 1.5 \\
\hline \multicolumn{10}{c}{ Source:The authors }
\end{tabular}

\subsection{Positioning the factors}

By compiling the survey results and computed results, the factors are ranked which are supposed to affect the country relations via political, economic, and social relations. Table 7, 8, 9 and 10 show the ranking calculated results.

Table 7 Comparison of factors while making country relations $(\mathrm{X})$

\begin{tabular}{l|c}
\hline Factors & Impact Value \\
\hline Economic action (Y2) & 0.7085 \\
\hline Political action (Y1) & 0.2261 \\
\hline Social action (Y3 & 0.0654 \\
\hline
\end{tabular}

Table 8 Comparison of factors contribution while making country relations via political actions (Y1)

\begin{tabular}{l|l}
\hline Factors & Impact Value \\
\hline Defence Co-operation & 0.5774 \\
\hline Country image & 0.2459 \\
\hline War on Terror & 0.1295 \\
\hline Regional Stability & 0.0471 \\
\hline Defence Co-operation & 0.5774 \\
\hline
\end{tabular}

Table 9 Comparison of factors contribution while making country relations via Social actions (Y2)

\begin{tabular}{l|l}
\hline Factors & Impact Value \\
\hline Cultural Exchange & 0.5923 \\
\hline Cooperation in the disaster & 0.2350 \\
\hline Education Exchanges & 0.1216 \\
\hline Health Services & 0.0510 \\
\hline Cultural Exchange & 0.5923 \\
\hline \multicolumn{2}{c}{ Source:The authors }
\end{tabular}

Table 10 Comparison of factors contribution while making country relations via economic actions $(\mathrm{Y} 3)$

\begin{tabular}{l|l}
\hline Factors & Impact Value \\
\hline Trade Co-operation & 0.5962 \\
\hline Energy Co-operation & 0.2449 \\
\hline FDI & 0.1129 \\
\hline Infrastructure & 0.0460 \\
\hline
\end{tabular}

\subsection{Mathematical equation for measuring country relations in President Xi's visit}

Based on the impact values and the levels of the factors the country relations calculation mathematical equation was composed as:

Set $t^{3} i(=1,2, \ldots, 14)$ is the final points for fourteen factors.

$$
w_{i j}^{2}, w_{i j}^{1}(i=1,2 \ldots \ldots \ldots . . m ; j=1,2, \ldots \ldots . n)
$$

Through this formula the relative impact value of $i$ in the middle or lowest level compare to $i$ in this 
level, $\mathrm{m}, \mathrm{n}$; is the total number of factors in this and its bellow level, then the score of $\mathrm{k}$-th level relative to $(\mathrm{k}+1)$ the level can be computed as :

$$
t_{i}^{k}=\sum_{j=1}^{n} w_{i j}^{k+1} t_{j}^{k+1} \quad(\mathrm{k}=3,2,1 j=1,2,3 \ldots \ldots m)
$$

After calculating $t i$ in every level, the following model can be used as measure for the country relations in the president's trip

$$
W=\frac{1}{10} \sum_{i=1}^{3} t_{i}^{1} \times 100^{\circ}
$$

Here $t_{1}^{1}, t_{2}^{1}, t_{3}^{1}$ are stands for ranking values for economic actions (Y1), political actions (Y2), and social actions (Y3) relative to country relations in president Xi's visit. The $\mathrm{W}$ is the total score of country relations in the specified visit.

\section{Conclusions}

Now, it is possible to measure country relations through the quantitative way, which was previously estimated by qualitative techniques. In this study, the ranking and weights of the matrices show that during Xi's visit to Pakistan in 2015, the significant contributions towards China Pakistan relations were more economical (Table 8 results). The same results can also be seen in the literature, where researchers described that China-Pakistan relations are more economical $(0.70 \%)$ than political $(0.22 \%)$ or social $(0.06 \%)$. The study conducted by Jian and Rashid who show that the relations seem to be more economical in the history and the trade provides China access to a new market for its goods and a foreign investment opportunity for Pakistan (Jian and Rashid 2011). In January 2000 Pakistan's Chief executive General Pervez Musharraf's visit to China and in 2001 Chinese primer Zhou Rongji's visit to Pakistan were also concluded with the bilateral economic relations. On April 2005, Chinese Premier Wen Jiabao's visited Pakistan and signed twenty-one agreements to promote close trade, and economic ties also show the industrial relations of both countries. In 2009, the President of Pakistan Asif Ali Zardari's visit to Chinese provinces Hangzhou and Guangzhou and signing a Memorandum of Understanding for cooperation in the field of fisheries (economic relations) also supported the results of this study. In 2014 and 2015 several visits to both countries also highlight the economic cooperation. Thus, this study contributes to the literature in the sense that it provides a mathematical and statistical equation to measure the factors contributing to country relations in any country head/delegation visit to any other country. Future studies may include some other factors besides political, economic, and social actions to measure the country relations quantitatively.sm

\section{References}

AbdulHaq, K. (2015). Sino-pak economic relations: the challenges and lessons for Pakistan. Guangdong: South China University of Technology.

Abid, M., \& Ashfaq, A. (2015). CPEC: Challenges and opportunities for Pakistan. Journal of Pakistan Vision, 16 (2), 142-169.

Afridi, J., \& Bajoria, J. (2010). China-Pakistan Relations. Retrieved July 15, 2019 from Council on Foreign Relations: https://www.cfr.org/backgrounder/chinapakistan-relations

Ahmar, M. (2015). Strategic Meaning of the China-Pakistan Economic Corridor. Retrieved July 15, 2019 from: Institute of Strategic Studies Islamabad: http://issi.org.pk/wp-content/uploads/2015/12/MoonisAhmar_3435_SS_41_20142015.pdf

Bijian, Z. (2005). China's "Peaceful Rise" to Great-Power Status. Foreign Affairs, 84 (5), 18-24. https://doi.org/10.2307/20031702

Chen, X., Joseph, S., \& Tariq, H. (2018). Betting Big on CPEC. Retrieved July 15, 2019 from: https://www.trincoll.edu/UrbanGlobal/CUGS/about/Docu ments/Chen\%20Joseph\%20Tariq\%20on\%20CPECTEFR\%20FebMarch\%202018.pdf

Fallon, T. (2015). The new silk road: Xi Jinping's grand strategy for Eurasia. American Foreign Policy Interests, 37 (3), 140-147. https://doi.org/10.1080/10803920.2015.1056682

Hali, S. M., Shukui, T., \& Iqbal, S. (2015). One Belt and One Road: Impact on China-Pakistan Economic Corridor. Strategic Studies, 34 (4), 147-164.

Haq, R., \& Farooq, N. (2016). Impact of CPEC on social welfare in Pakistan: A district level analysis. Paper presented at the $32^{\text {nd }}$ Annual General Meeting and Conference, Pakistan Society of Development Economics, Pakistan Institute of Development Economics, Islamabad, Pakistan.

Hardingham, E., Vrbka, J., Kliestik, T., \& Kliestikova, J. (2018). Will Cognitive Technology-Driven Automation Lead to Economic Growth? Journal of Self-Governance and Management Economics, 6 (4), 13-18. https://doi.org/10.22381/JSME6420182

Heilmann, S., Rudolf, M., Huotari, M., \& Buckow, J. (2014). China's shadow foreign policy: parallel structures challenge the established international order. China Monitor, 18, 28.

Kataria, J. R., \& Naveed, A. (2014). Pakistan-China social and economic relations. South Asian Studies, 29 (2), 395-410.

Kazimi, M. R. (2016). China-Pakistan Relations. Pakistan Perspectives, 21 (2), 217.

Khan, A. U. (2014). Pak-China economic corridor: The hopes and reality. Institute of Regional Studies, Islamabad, Retrieved July 15, 2019 from: http://irs.org.pk/spotlight/spjan15.pdf 
Mitea, D. R. E. (2018). The expansion of digitally mediated labor: platform-based economy, technology-driven shifts in employment, and the novel modes of service work. Journal of Self-Governance and Management Economics, 6 (4), 7-13. https://doi.org/10.22381/JSME6420181

Neary, B., Horák, J., Kovacova, M., \& Valaskova, K. (2018). The future of work: Disruptive business practices, technology-driven economic growth, and computerinduced job displacement. Journal of Self-Governance and Management Economics, 6 (4), 19-24. https://doi.org/10.22381/JSME6420183

Nica, E. (2018). Gig-based Working Arrangements: Business Patterns, Labor-Management Practices, and Regulations. Economics, Management, and Financial Markets, 13 (1), 100-105. https://doi.org/10.22381/EMFM13120185

Pantucci, R. (2014). China in Pakistan: An awkward relationship beneath the surface. Retrieved July 15 , 2019 from:

https://raffaellopantucci.com/2014/01/15/china-inpakistan-an-awkward-relationship-beneath-the-surface/

Popescu, G. H. (2018). Participation in the sharing economy: Labor, exchange, and consumption. An

\section{$\bowtie$ Correspondence}

\section{Sajjad Ali}

School of Sociology and Political Science, Shanghai University, 99 Shangda Road, Baoshan District, Shanghai China

Email: sajjad@shu.edu.cn empirical analysis. Journal of Self-Governance and Management Economics, 6 (1), 122-127. https://doi.org/10.22381/JSME6120185

Rizvi, H. A. (2015). The China-Pakistan Economic Corridor: Regional Cooperation and Socio-Economic Development. Strategic Studies, 34 (4), 1-17.

Saaty, T. L. (2008). Decision making with the analytic hierarchy process. International journal of services sciences, 1(1), 83-98. https://doi.org/10.1504/IJSSCl.2008.017590

Sattar, A. (2007). Pakistan's foreign policy, 1947-2005: A concise history. Oxford: Oxford University Press.

Tao, J. (2012). Years of Pak-China Relations Landmarks. Trends and Approaches. Islamabad: Institute of policy studies Islamabad. 